\title{
Gracilibacillus thailandensis sp. nov., from fermented fish (pla-ra)
}

\author{
Nitcha Chamroensaksri, ${ }^{1}$ Somboon Tanasupawat, ${ }^{1}$ \\ Ancharida Akaracharanya, ${ }^{2}$ Wonnop Visessanguan, ${ }^{3}$ Takuji Kudo ${ }^{4}$ \\ and Takashi Itoh ${ }^{4}$ \\ ${ }^{1}$ Department of Microbiology, Faculty of Pharmaceutical Sciences, Chulalongkorn University, \\ Bangkok 10330, Thailand \\ ${ }^{2}$ Department of Microbiology, Faculty of Science, Chulalongkorn University, Bangkok 10330, \\ Thailand \\ ${ }^{3}$ National Center for Genetic Engineering and Biotechnology, Pathumthani 12120, Thailand \\ ${ }^{4}$ Japan Collection of Microorganisms, RIKEN BioResource Center, 2-1 Hirosawa, Wako-shi, \\ Saitama 351-0198, Japan
}

Correspondence

Somboon Tanasupawat Somboon.T@chula.ac.th

\begin{abstract}
A novel strain, designated TP2-8 ${ }^{\top}$, was isolated from fermented fish (pla-ra) in Thailand. It stained Gram-positive and the cells were aerobic, endospore-forming rods. The strain grew at $\mathrm{pH} 6-8$

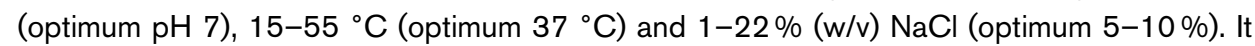
contained meso-diaminopimelic in the cell-wall peptidoglycan. MK-7 and cellular fatty acids anteiso- $\mathrm{C}_{15: 0}$, iso- $\mathrm{C}_{15: 0}$ and anteiso- $\mathrm{C}_{17: 0}$ were major components. Polar lipids diphosphatidylglycerol and phosphatidylglycerol and unidentified lipids were detected. The DNA $\mathrm{G}+\mathrm{C}$ content was $37.6 \mathrm{~mol} \%$. Comparison of the $16 \mathrm{~S}$ rRNA gene sequence of strain TP2-8 ${ }^{\top}$ with those of other members of the family Bacillaceae indicated that it was a member of the genus Gracilibacillus (94.9-99.2\% sequence similarity) and was closely related to Gracilibacillus saliphilus YIM $91119^{\top}$ (99.2\% similarity), G. lacisalsi $\mathrm{BH} 312^{\top}(98.6 \%)$, G. orientalis $\mathrm{XH}^{\top} 63^{\top}$ (97.7\%), 'G. quinghaiensis' YIM C229 (97.7\%) and G. boraciitolerans T-16X' (97.2\%). Strain TP2-8 ${ }^{\top}$ showed low DNA-DNA relatedness ( $\left.\leqslant 49 \%\right)$ to G. saliphilus YIM $91119^{\top}$, G. lacisalsi DSM $19029^{\top}$, G. orientalis CCM $7326^{\top}$, 'G. quinghaiensis' DSM 17858 and G. boraciitolerans JCM $21714^{\top}$. On the basis of the physiological and biochemical characteristics and molecular data presented, strain TP2-8 ${ }^{\top}$ is proposed to represent a novel species, Gracilibacillus thailandensis sp. nov. (type strain TP2-8 $8^{\top}=\mathrm{JCM} 15569^{\top}=\mathrm{PCU} 304^{\top}=\operatorname{TISTR} 1881^{\top}$ ).
\end{abstract}

The genus Gracilibacillus was described by Wainø et al. (1999) to accommodate moderately halophilic, endospore-forming bacteria. At the time of writing, the genus comprises seven species with validly published names: Gracilibacillus halotolerans, the type species, from surface mud of the Great Salt Lake (Wainø et al., 1999), G. dipsosauri, from a desert iguana (Lawson et al., 1996), G. orientalis (Carrasco et al., 2006), G. lacisalsi (Jeon et al., 2008) and G. saliphilus (Tang et al., 2009), from saline lakes, G. boraciitolerans, from soil (Ahmed et al., 2007) and G. halophilus, from a saline soil (Chen et al., 2008b). 'Gracilibacillus quinghaiensis' has been described

The GenBank/EMBL/DDBJ accession number for the 16S rRNA gene sequence of strain TP2-8 ${ }^{\top}$ is FJ182214.

16S rRNA gene sequence-based maximum-parsimony and maximumlikelihood trees, fatty acid profiles of strain TP2-8 ${ }^{\top}$ and related strains and detailed DNA-DNA hybridization results are available as supplementary material with the online version of this paper. from a salt-lake sediment (Chen et al., 2008a), but this name has not yet been validly published. These bacteria thrive in a maximum of $11-30 \% \mathrm{NaCl}$ and at $50{ }^{\circ} \mathrm{C}$. Moderately halophilic bacteria are also found in many kinds of fermented food, including Jeotgalibacillus alimentarius, from jeotgal (Yoon et al., 2001), Lentibacillus juripiscarius and Lentibacillus halophilus, from fish sauce (Namwong et al., 2005; Tanasupawat et al., 2006), Lentibacillus kapialis, from fermented shrimp paste (Pakdeeto et al., 2007), and Piscibacillus salipiscarius, from fermented fish (pla-ra) (Tanasupawat et al., 2007). In the course of a study on bacterial diversity in fermented foods in Thailand, we isolated a novel Gracilibacillus-like strain, designated $\mathrm{TP} 2-8^{\mathrm{T}}$, from pla$r a$, a traditional fermented fish, containing 7.8-17.9\% $\mathrm{NaCl}$ (w/v) (Phithakpol et al., 1995). In this paper, we describe its phenotypic and chemotaxonomic characteristics, including DNA-DNA relatedness and 16S rRNA gene sequence analyses. 
Strain TP2-8 ${ }^{\mathrm{T}}$ was isolated from pla-ra collected from a market in Nonthaburi province, Thailand. The strain was isolated from the sample by the spread-plate technique on JCM no. 377 agar plates $\left(1^{-1}: 100 \mathrm{~g} \mathrm{NaCl}, 5 \mathrm{~g}\right.$ Casamino acids, $5 \mathrm{~g}$ yeast extract, $1 \mathrm{~g}$ glutamic acid, $2 \mathrm{~g} \mathrm{KCl}, 3 \mathrm{~g}$ trisodium citrate, $20 \mathrm{~g} \mathrm{MgSO} 4.7 \mathrm{H}_{2} \mathrm{O}, 36 \mathrm{mg} \mathrm{FeCl} 2.4 \mathrm{H}_{2} \mathrm{O}$, $0.36 \mathrm{mg} \mathrm{MnCl}{ }_{2} .4 \mathrm{H}_{2} \mathrm{O}, 20 \mathrm{~g}$ agar; $\mathrm{pH} 7.2$ ) and incubated at $30{ }^{\circ} \mathrm{C}$ for $3-7$ days. Cell shape, size and arrangement were examined on JCM no. 377 agar at $30{ }^{\circ} \mathrm{C}$ after 3 days. The modification of Hucker \& Conn (1923) was used for Gram staining. Cell form and spore formation were observed under scanning electron microscopy. Flagella were examined as described by Forbes (1981). Growth at various $\mathrm{NaCl}$ concentrations was investigated in JCM no. 377 broth, with $\mathrm{MgSO}_{4} \cdot 7 \mathrm{H}_{2} \mathrm{O}$ omitted and with the addition of various concentrations of $\mathrm{NaCl}(0,0.5 \%$, w/v, and $1-25 \%$ at intervals of $1 \%$ ). Growth at $\mathrm{pH} 5-10$ (at intervals of $1 \mathrm{pH}$ unit) and 15, 25, 30, 37, 40, 45, 50 and $55{ }^{\circ} \mathrm{C}$ was investigated in JCM no. 377 broth (Namwong et al., 2005). Catalase and oxidase activity, indole production, the methyl red/Voges-Proskauer reaction, $\mathrm{H}_{2} \mathrm{~S}$ production and nitrate reduction were determined as described by Barrow \& Feltham (1993). JCM no. 377 medium with $0.25 \%$ agar, $1 \%$ glucose and bromcresol purple as indicator was used for the oxidative/fermentative (OF) test. Hydrolysis of aesculin, casein, gelatin, starch, Tween 80 , urea, xanthine and hypoxanthine was determined as described by Namwong et al. (2005). Arginine decarboxylase was determined by using the medium reported by Thornley (1960). Acid production from carbohydrates was determined in the medium described by Leifson (1963). All tests were carried out in medium supplemented with $10 \%$ $\mathrm{NaCl}$ (except for the investigation of effects of $\mathrm{NaCl}$ on growth). The ability to utilize various compounds was examined in a medium described by Carrasco et al. (2006) supplemented with $10 \% \mathrm{NaCl}$. Carbohydrates were used at a final concentration of $0.5 \%(\mathrm{w} / \mathrm{v})$. When amino acids were used as substrates, the basal medium contained neither $\mathrm{KNO}_{3}$ nor $\left(\mathrm{NH}_{4}\right)_{2} \mathrm{HPO}_{4}$. Growth under anaerobic conditions on JCM no. 377 agar plates with or without $\mathrm{KNO}_{3}(1 \%$, w/v when present) was performed in a Gaspak anaerobic jar (BBL). Antibiotic susceptibility was determined according to the conventional Kirby-Bauer method (Bauer et al., 1966). Plates were incubated at $30{ }^{\circ} \mathrm{C}$ for $48 \mathrm{~h}$ and inhibition zones were interpreted according to the manufacturer's manual (Oxoid).

Cell biomass was produced in JCM medium no. 377 at $30{ }^{\circ} \mathrm{C}$ for 3 days for chemotaxonomic characterization. Diaminopimelic acid in the cell wall and the menaquinone profile were determined as described by Komagata \& Suzuki (1987). Polar lipids were extracted as described by Minnikin et al. (1984) and identified by two-dimensional TLC followed by spraying with appropriate detection reagents (Komagata \& Suzuki, 1987). For quantitative analysis of cellular fatty acid compositions, cell mass was harvested and fatty acid methyl esters were prepared and identified according to the instructions of the Microbial
Identification System (MIDI) (Sasser, 1990; Kämpfer \& Kroppenstedt, 1996). Chromosomal DNA was isolated and purified from cells grown in JCM medium no. 377 according to the method of Saito \& Miura (1963). The DNA $\mathrm{G}+\mathrm{C}$ content was determined by reversed-phase HPLC (Tamaoka \& Komagata, 1984). DNA-DNA hybridization was conducted in microwell plates as reported by Ezaki et al. (1989). The 16S rRNA gene of the isolate was amplified, purified and sequenced as described by Namwong et al. (2005). The sequence determined was aligned with selected sequences obtained from the GenBank/EMBL/DDBJ databases employing CLUSTAL_X version 1.83 (Thompson et al., 1997). The alignment was edited manually, and positions with gaps and ambiguous bases were eliminated prior to construction of phylogenetic trees. Phylogenetic trees based on the neighbour-joining method (Saitou \& Nei, 1987) as well as the maximumparsimony and maximum-likelihood methods were constructed by using the NJplot program (Perrière \& Gouy, 1996) in the MEGA 4 software (Tamura et al., 2007). Confidence values of branches of the phylogenetic tree were determined using bootstrap analyses (Felsenstein, 1985) based on 1000 resamplings.

Cells of strain TP2-8 $8^{\mathrm{T}}$ were Gram-stain-positive rods, approximately $0.3-0.4 \mu \mathrm{m}$ wide and 3-4 $\mu \mathrm{m}$ long after 3 days of incubation at $37^{\circ} \mathrm{C}$ on JCM no. 377 agar (Fig. 1). Oval endospores were produced at a terminal position in swollen sporangia. Cells were motile by means of peritrichous flagella. Colonies were circular, translucent and white to cream in colour (diameter $0.2-0.5 \mathrm{~mm}$ ). The strain utilized glucose oxidatively. Phenotypic characteristics are listed in the species description and in Table 1. This strain contained MK-7 as the major menaquinone. Major cellular fatty acids were anteiso- $\mathrm{C}_{15: 0}(37.6 \%)$, iso$\mathrm{C}_{15: 0}(16.1 \%)$ and anteiso- $\mathrm{C}_{17: 0}(12.9 \%)$. The strain showed a similar fatty acid profile to that of its closest relative, G. saliphilus YIM 91119 ${ }^{\mathrm{T}}$ (Supplementary Table S1, available in IJSEM Online). Polar lipid fractions contained diphosphatidylglycerol, phosphatidylglycerol, an unidentified glycolipid and an unidentified polar lipid. The DNA

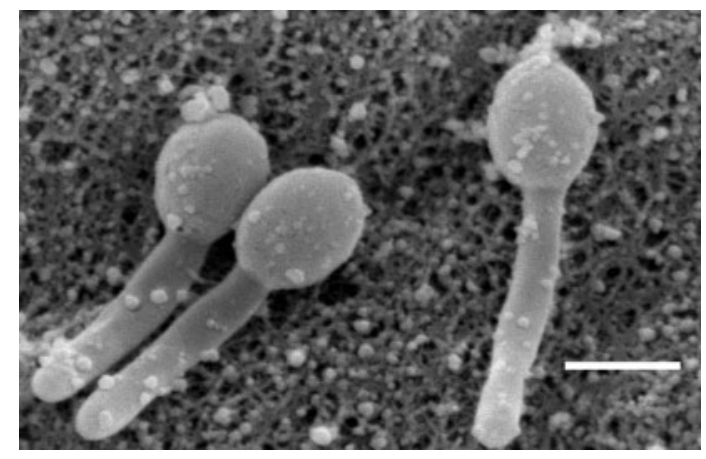

Fig. 1. Scanning electron micrograph of cells of strain TP2-8 ${ }^{\top}$ grown on JCM no. 377 medium at $37{ }^{\circ} \mathrm{C}$. Bar, $1 \mu \mathrm{m}$. 
Table 1. Differential characteristics of TP2-8 ${ }^{\top}$ and type strains of Gracilibacillus species

Strains: 1, TP2-8 ${ }^{\mathrm{T}}$ (data from this study); 2, G. saliphilus YIM 91119 (Tang et al., 2009); 3, G. lacisalsi DSM 19029 ${ }^{\mathrm{T}}$ (Jeon et al., 2008); 4, G. orientalis CCM $7326^{\mathrm{T}}$ (Carrasco et al., 2006); 5, 'G. quinghaiensis' DSM 17858 (Chen et al., 2008a); 6, G. boraciitolerans JCM 21714 ${ }^{\mathrm{T}}$ (Ahmed et al., 2007); 7, G. halotolerans JCM 7302 ${ }^{\mathrm{T}}$ (Wainø et al., 1999); 8, G. dipsosauri JCM 7303 ${ }^{\mathrm{T}}$ (Wainø et al., 1999); 9, G. halophilus DSM 17856 ${ }^{\mathrm{T}}$ (Chen et al., 2008b). Data were obtained from the sources listed unless indicated. +, Positive; w, weakly positive; - , negative; ND, no data available.

\begin{tabular}{|c|c|c|c|c|c|c|c|c|c|}
\hline Characteristic & 1 & 2 & 3 & 4 & 5 & 6 & 7 & 8 & 9 \\
\hline Spore shape ${ }^{\star}$ & $\mathrm{O}$ & $\mathrm{s}$ & $\mathrm{s}$ & $\mathrm{s}$ & $\mathrm{E}$ & $\mathrm{s}$ & $\mathrm{E}$ & s & $\mathrm{E}$ \\
\hline \multicolumn{10}{|c|}{$\mathrm{NaCl}$ concentration for growth $(\%, w / v)$} \\
\hline Range & $1-22$ & $1-22 \dagger$ & $0.5-18 \dagger$ & $3-20 \dagger$ & $0.5-8$ & $0-11$ & $0-20$ & $0-15$ & $7-30$ \\
\hline Optimum & $5-10$ & $10-15 \dagger$ & $5-7 \dagger$ & $10 \dagger$ & $1-3$ & $0.5-3$ & 0 & 3 & 15 \\
\hline \multicolumn{10}{|l|}{ Temperature for growth $\left({ }^{\circ} \mathrm{C}\right)$} \\
\hline Range & $15-55$ & $4-45$ & $15-50$ & $15-45 \dagger$ & $4-45$ & $11-37$ & $6-50$ & $28-50$ & $28-60$ \\
\hline Optimum & 37 & 37 & 40 & $37 \dagger$ & 37 & $25-28$ & 47 & 45 & $45-50$ \\
\hline \multicolumn{10}{|l|}{$\mathrm{pH}$ for growth } \\
\hline Range & $6-8$ & $6-8$ & $5.5-10$ & $5-9 \dagger$ & $6-8.5$ & $6-10$ & $5-10$ & ND & $6-9$ \\
\hline Optimum & 7 & 7 & $7.5-8$ & $7 \dagger$ & $7-7.5$ & $7.5-8.5$ & 7.5 & 7.5 & 7 \\
\hline Nitrate reduction $\dagger$ & + & + & + & - & + & - & + & + & + \\
\hline \multicolumn{10}{|l|}{ Hydrolysis of: $\dagger$} \\
\hline Gelatin & + & - & - & + & - & - & + & + & + \\
\hline Starch & - & + & - & - & - & + & + & - & + \\
\hline Urea & - & + & - & - & + & - & + & - & $\mathrm{ND}$ \\
\hline \multicolumn{10}{|l|}{ Acid from: $\dagger$} \\
\hline Glycerol & + & - & + & - & $\mathrm{w}$ & + & ND & - & $\mathrm{w}$ \\
\hline Lactose & - & + & - & - & - & + & ND & + & - \\
\hline Melezitose & + & - & - & - & - & + & ND & - & - \\
\hline \multicolumn{10}{|l|}{ Carbon source utilization: $\dagger$} \\
\hline L-Aspartic acid & - & + & + & - & ND & ND & ND & $\mathrm{ND}$ & ND \\
\hline Glycine & - & + & - & - & $\mathrm{ND}$ & ND & ND & ND & $\mathrm{ND}$ \\
\hline L-Lysine & - & + & - & - & ND & ND & ND & ND & ND \\
\hline Raffinose & + & - & + & + & $\mathrm{ND}$ & $\mathrm{ND}$ & $\mathrm{ND}$ & $\mathrm{ND}$ & ND \\
\hline Sodium acetate & - & + & - & + & $\mathrm{ND}$ & ND & ND & ND & ND \\
\hline DNA G $+\mathrm{C}$ content $(\mathrm{mol} \%)$ & 37.6 & 40.1 & 39 & 37.1 & 40.9 & 35.8 & 38 & 39.4 & 42.3 \\
\hline
\end{tabular}

${ }^{\star} \mathrm{E}$, Ellipsoidal; O, oval; s, spherical.

$\dagger$ Data from this study.

$\mathrm{G}+\mathrm{C}$ content was $37.6 \mathrm{~mol} \%$. Comparison of the $16 \mathrm{~S}$ rRNA gene sequence of strain TP2- $8^{\mathrm{T}}(1500 \mathrm{nt})$ with those of other members of the family Bacillaceae indicated that it was placed in the genus Gracilibacillus and was closely related to G. saliphilus YIM $91119^{\mathrm{T}}(99.2 \%$ similarity), G. lacisalsi $\mathrm{BH} 312^{\mathrm{T}}(98.6 \%)$, G. orientalis $\mathrm{XH}-63^{\mathrm{T}}(97.7 \%)$, 'G. quinghaiensis' YIM C229 (97.7\%), G. boraciitolerans T$16 \mathrm{X}^{\mathrm{T}}(97.2 \%)$, G. dipsosauri $\mathrm{DD}^{\mathrm{T}}(96.4 \%)$, G. halotolerans $\mathrm{NN}^{\mathrm{T}}(95.8 \%)$ and G. halophilus YIM-C55.5 ${ }^{\mathrm{T}}(94.9 \%)$ (Fig. 2). Phylogenetic trees based on other algorithms are shown as Supplementary Figs S1 and S2. In agreement with the phylogenetic assignment, the phenotypic properties of strain TP2-8 ${ }^{\mathrm{T}}$, such as its cell morphology, the $\mathrm{NaCl}$ concentration range for growth, the presence of diaminopimelic acid in the cell wall, major menaquinone composition, fatty acid profile and DNA G+C content, are consistent with the assignment of strain $\mathrm{TP} 2-8^{\mathrm{T}}$ to the genus Gracilibacillus. DNA-DNA hybridization studies showed that strain TP2-8 ${ }^{\mathrm{T}}$ had low levels of DNA-DNA relatedness ( $\leqslant 49 \%$ ) to G. saliphilus YIM $91119^{\mathrm{T}}$, G. lacisalsi DSM $19029^{\mathrm{T}}$, G. orientalis CCM $7326^{\mathrm{T}}$, 'G. quinghaiensis' DSM 17858, G. boraciitolerans JCM $21714^{\mathrm{T}}$, G. halotolerans JCM $7303^{\mathrm{T}}$, G. dipsosauri JCM $7302^{\mathrm{T}}$ and G. halophilus DSM $17856^{\mathrm{T}}$ (Supplementary Table S2), well below the level of $70 \%$ recommended for species delineation by Wayne et al. (1987). In addition, strain TP2-8 ${ }^{\mathrm{T}}$ and its closest relative, G. saliphilus YIM $91119^{\mathrm{T}}$, showed differences in sensitivity to ampicillin $(10 \mu \mathrm{g})$, gentamicin $(10 \mu \mathrm{g})$, novobiocin $(30 \mu \mathrm{g})$ and chloramphenicol $(30 \mu \mathrm{g})$ (this study; Tang et al., 2009). Strain TP2-8 ${ }^{\mathrm{T}}$ was distinguished from Gracilibacillus species by spore shape, ranges of $\mathrm{NaCl}$ concentration, temperature and $\mathrm{pH}$ for growth, biochemical characteristics, acid production and carbon source utilization and $\mathrm{G}+\mathrm{C}$ content, as shown in Table 1. On the basis of its phenotypic and genotypic properties, strain TP2-8 ${ }^{\mathrm{T}}$ represents a novel species of the genus Gracilibacillus, for which we propose the name Gracilibacillus thailandensis sp. nov. 


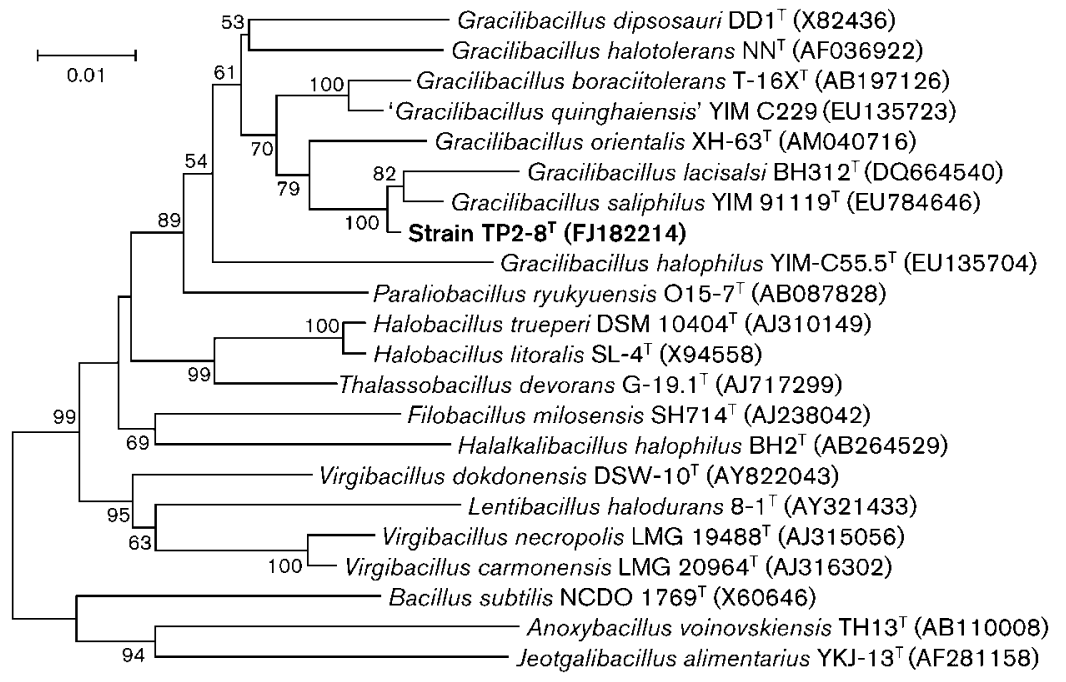

Fig. 2. Phylogenetic tree showing relationships between strain TP2-8 ${ }^{\top}$, Gracilibacillus species and related taxa based on $16 \mathrm{~S}$ rRNA gene sequences. The branching pattern was generated by the neighbour-joining method. Bootstrap percentages $\geqslant 53 \%$ based on 1000 replications are shown at nodes. Bar, 0.01 substitutions per nucleotide position. Maximum-likelihood and maximum-parsimony trees are available as Supplementary Figs S1 and S2.

\section{Description of Gracilibacillus thailandensis sp. nov.}

Gracilibacillus thailandensis (thai.lan.den'sis. N.L. masc. adj. thailandensis pertaining to Thailand, where the type strain was isolated).

Cells are Gram-stain-positive rods, approximately 0.3$0.4 \mu \mathrm{m}$ wide and 3-4 $\mu \mathrm{m}$ long. Oval endospores are produced in a terminal position in swollen sporangia. Motile by means of peritrichous flagella. Colonies are circular, translucent, white and $0.2-0.5 \mathrm{~mm}$ in diameter. Strictly aerobic. Utilizes glucose oxidatively. Grows at pH 6-8 (optimum pH 7), $15-55^{\circ} \mathrm{C}$ (optimum $37{ }^{\circ} \mathrm{C}$ ) and $1-22 \%(\mathrm{w} / \mathrm{v}) \mathrm{NaCl}$ (optimum $5-10 \%$ ), but not in $0.5 \%$ $\mathrm{NaCl}$ or below. No growth under anaerobic conditions even if $\mathrm{KNO}_{3}$ is added. Catalase, oxidase, methyl red test, nitrate reduction and hydrolysis of aesculin and gelatin are positive. Negative for indole production, Voges-Proskauer reaction, hydrolysis of casein, starch, Tween 80 , urea, Ltyrosine, xanthine and hypoxanthine, arginine dihydrolase activity and production of $\mathrm{H}_{2} \mathrm{~S}$. Susceptible to ampicillin $(10 \mu \mathrm{g})$, gentamicin $(10 \mu \mathrm{g})$, kanamycin $(30 \mu \mathrm{g})$, neomycin $(30 \mu \mathrm{g})$, novobiocin $(30 \mu \mathrm{g})$ and rifampicin $(30 \mu \mathrm{g})$, but resistant to bacitracin $(10 \mathrm{U})$, chloramphenicol $(30 \mu \mathrm{g})$ and nalidixic acid $(30 \mu \mathrm{g})$. Acid is produced from $\mathrm{L}-$ arabinose, cellobiose, D-fructose, D-galactose, D-glucose, glycerol, maltose, D-mannitol, D-mannose, melibiose, melezitose, raffinose, rhamnose, ribose, salicin, sucrose, trehalose and D-xylose but not from inulin, myo-inositol, lactose, sorbitol, ribitol or arabitol. Utilizes L-arginine, cellobiose, galactose, lactose, D-mannose, melezitose, raffinose, sodium citrate and trehalose but not glycine, Laspartic acid, L-cysteine, L-glutamic, hippuric acid, L-lysine, L-ornithine, L-phenylalanine, sodium acetate, sodium pyruvate, sodium benzoate, L-threonine or D-xylose as sole sources of carbon and nitrogen (the latter where appropriate). Contains diaminopimelic acid in the cell wall and MK-7 as the major menaquinone. Major cellular fatty acids are anteiso- $C_{15: 0}$, iso- $C_{15: 0}$ and anteiso- $C_{17: 0}$. The major polar lipids are diphosphatidylglycerol, phosphatidylglycerol, an unidentified glycolipid and an unidentified polar lipid. The DNA G+C content of the type strain is $37.6 \mathrm{~mol} \%$.

The type strain, TP2-8 $8^{\mathrm{T}}\left(=\mathrm{JCM} \quad 15569^{\mathrm{T}}=\mathrm{PCU} 304^{\mathrm{T}}\right.$ $=$ TISTR $1881^{\mathrm{T}}$ ), was isolated from pla-ra, a traditional fermented fish, in Thailand.

\section{Acknowledgements}

We are very grateful to the Thailand Research Fund for a 2005 Royal Golden Jubilee Scholarship as a research grant to N.C. and for a Faculty of Pharmaceutical Sciences research grant (2005). The authors thank Dr Wen-Jun Li (Yunnan Institute of Microbiology, Kunming, PR China) for providing G. saliphilus YIM $91119^{\mathrm{T}}$.

\section{References}

Ahmed, I., Yokota, A. \& Fujiwara, T. (2007). Gracilibacillus boraciitolerans sp. nov., a highly boron-tolerant and moderately halotolerant bacterium isolated from soil. Int J Syst Evol Microbiol 57, 796-802.

Barrow, G. I. \& Feltham, R. K. A. (1993). Cowan and Steel's Manual for the Identification of Medical Bacteria, 3rd edn. Cambridge: Cambridge University Press.

Bauer, A. W., Kirby, W. M., Sherris, J. C. \& Turck, M. (1966). Antibiotic susceptibility testing by a standardized single disk method. Am J Clin Pathol 45, 493-496.

Carrasco, I. J., Márquez, M. C., Yanfen, X., Ma, Y., Cowan, D. A., Jones, B. E., Grant, W. D. \& Ventosa, A. (2006). Gracilibacillus orientalis sp. nov., a novel moderately halophilic bacterium isolated from a salt lake in Inner Mongolia, China. Int J Syst Evol Microbiol 56, 599-604.

Chen, Y. G., Cui, X. L., Zhang, Y. Q., Li, W. J., Wang, Y. X., Xu, L. H., Peng, Q., Wen, M. L. \& Jiang, C. L. (2008a). Gracilibacillus quinghaiensis sp. nov., isolated from salt-lake sediment in the Qaidam Basin, north-west China. Syst Appl Microbiol 31, 183189.

Chen, Y. G., Cui, X. L., Zhang, Y. Q., Li, W. J., Wang, Y. X., Xu, L. H., Peng, Q., Wen, M. L. \& Jiang, C. L. (2008b). Gracilibacillus halophilus 
sp. nov., a moderately halophilic bacterium isolated from saline soil. Int J Syst Evol Microbiol 58, 2403-2408.

Ezaki, T., Hashimoto, Y. \& Yabuuchi, E. (1989). Fluorometric deoxyribonucleic acid-deoxyribonucleic acid hybridization in microdilution wells as an alternative to membrane filter hybridization in which radioisotopes are used to determine genetic relatedness among bacterial strains. Int J Syst Bacteriol 39, 224-229.

Felsenstein, J. (1985). Confidence limits on phylogenies: an approach using the bootstrap. Evolution 39, 783-791.

Forbes, L. (1981). Rapid flagella stain. J Clin Microbiol 13, 807-809.

Hucker, G. J. \& Conn, H. J. (1923). Method of Gram staining. NY State Agric Exp Stn Tech Bull 93, 3-37.

Jeon, C. O., Lim, J. M., Jang, H. H., Park, D. J., Xu, L. H., Jiang, C. L. \& Kim, C. J. (2008). Gracilibacillus lacisalsi sp. nov., a halophilic Grampositive bacterium from a salt lake in China. Int J Syst Evol Microbiol 58, 2282-2286.

Kämpfer, P. \& Kroppenstedt, R. M. (1996). Numerical analysis of fatty acid patterns of coryneform bacteria and related taxa. Can J Microbiol 42, 989-1005.

Komagata, K. \& Suzuki, K. (1987). Lipid and cell-wall analysis in bacterial systematics. Methods Microbiol 19, 161-207.

Lawson, P. A., Deutch, C. E. \& Collins, M. D. (1996). Phylogenetic characterization of a novel salt-tolerant Bacillus species: description of Bacillus dipsosauri sp. nov. J Appl Bacteriol 81, 109-112.

Leifson, E. (1963). Determination of carbohydrate metabolism of marine bacteria. J Bacteriol 85, 1183-1184.

Minnikin, D. E., O'Donnell, A. G., Goodfellow, M., Alderson, G., Athalye, M., Schaal, A. \& Parlett, J. H. (1984). An integrated procedure for the extraction of bacterial isoprenoid quinones and polar lipids. J Microbiol Methods 2, 233-241.

Namwong, S., Tanasupawat, S., Smitinont, T., Visessanguan, W., Kudo, T. \& Itoh, T. (2005). Isolation of Lentibacillus salicampi strains and Lentibacillus juripiscarius sp. nov., from fish sauce in Thailand. Int J Syst Evol Microbiol 55, 315-320.

Pakdeeto, A., Tanasupawat, S., Thawai, C., Moonmangmee, S., Kudo, T. \& Itoh, T. (2007). Lentibacillus kapialis sp. nov., from fermented shrimp paste in Thailand. Int J Syst Evol Microbiol 57, 364369.

Perrière, G. \& Gouy, M. (1996). WWW-Query: an on-line retrieval system for biological sequence banks. Biochimie 78, 364-369.

Phithakpol, B., Varanyanond, W., Reungmaneepaitoon, S. \& Wood, H. (1995). The Traditional Fermented Foods of Thailand. Kuala Lumpur: ASEAN Food Handling Bureau Level 3.

Saito, H. \& Miura, K. I. (1963). Preparation of transforming deoxyribonucleic acid by phenol treatment. Biochim Biophys Acta 72, 619-629.
Saitou, N. \& Nei, M. (1987). The neighbor-joining method: a new method for reconstructing phylogenetic trees. Mol Biol Evol 4, 406425.

Sasser, M. (1990). Identification of bacteria by gas chromatography of cellular fatty acids, MIDI Technical Note 101. Newark, DE: MIDI Inc.

Tamaoka, J. \& Komagata, K. (1984). Determination of DNA base composition by reversed-phase high-performance liquid chromatography. FEMS Microbiol Lett 25, 125-128.

Tamura, K., Dudley, J., Nei, M. \& Kumar, S. (2007). MEGA 4: molecular evolutionary genetics analysis (MEGA) software version 4.0. Mol Biol Evol 24, 1596-1599.

Tanasupawat, S., Pakdeeto, A., Namwong, S., Thawai, C., Kudo, T. \& Itoh, T. (2006). Lentibacillus halophilus sp. nov., from fish sauce in Thailand. Int J Syst Evol Microbiol 56, 1859-1863.

Tanasupawat, S., Namwong, S., Kudo, T. \& Itoh, T. (2007). Piscibacillus salipiscarius gen. nov., sp. nov., a moderately halophilic bacterium from fermented fish (pla-ra) in Thailand. Int J Syst Evol Microbiol 57, 1413-1417.

Tang, S.-K., Wang, Y., Lou, K., Mao, P.-H., Jin, X., Jiang, C.-L., Xu, L.-H. \& Li, W.-L. (2009). Gracilibacillus saliphilus sp. nov., a moderately halophilic bacterium isolated from a saline lake. Int J Syst Evol Microbiol 59, 1620-1624.

Thompson, J. D., Higgins, D. G. \& Gibson, T. J. (1997). The CLUSTAL_X windows interface: flexible strategies for multiple sequence alignment aided by quality analysis tools. Nucleic Acids Res 25, 4876-4882.

Thornley, M. J. (1960). The differentiation of Pseudomonas from other Gram-negative bacteria on the basis of arginine metabolism. J Appl Microbiol 23, 37-52.

Wainø, M., Tindall, B. J., Schumann, P. \& Ingvorsen, K. (1999). Gracilibacillus gen. nov., with description of Gracilibacillus halotolerans gen. nov., sp. nov.; transfer of Bacillus dipsosauri to Gracilibacillus dipsosauri comb. nov., and Bacillus salexigens to the genus Salibacillus gen. nov., as Salibacillus salexigens comb. nov. Int J Syst Bacteriol 49, 821-831.

Wayne, L. G., Brenner, D. J., Colwell, R. R., Grimont, P. A. D., Kandler, O., Krichevsky, M. I., Moore, L. H., Moore, W. E. C., Murray, R. G. E. \& other authors (1987). International Committee on Systematic Bacteriology. Report of the ad hoc committee on reconciliation of approaches to bacterial systematics. Int J Syst Bacteriol 37, 463464.

Yoon, J.-H., Weiss, N., Lee, K. C., Lee, I. S., Kang, K. H. \& Park, Y.-H. (2001). Jeotgalibacillus alimentarius gen. nov., sp. nov., a novel bacterium isolated from jeotgal with L-lysine in the cell wall, and reclassification of Bacillus marinus Rüger 1983 as Marinibacillus marinus gen. nov., comb. nov. Int J Syst Evol Microbiol 51, 20872093. 